\title{
Morphological Analysis of Narrow-petaled Cultivars of Rhododendron macrosepalum Maxim.
}

\author{
Keisuke Tasaki ${ }^{1}$, Akira Nakatsuka ${ }^{2}$ and Nobuo Kobayashi ${ }^{2 *}$ \\ ${ }^{1}$ The United Graduate School of Agricultural Sciences, Tottori University, Tottori 680-8553, Japan \\ ${ }^{2}$ Faculty of Life and Environmental Sciences, Shimane University, Matsue 690-8504, Japan
}

In evergreen azalea, unique old mutational cultivars, whose flower have split figure, have been collected and is called "sai-zaki" in Japanese. The morphology of leaves and flowers of the wild-type and sai-zaki cultivars 'Hanaguruma', 'Gin-no-zai', and 'Seigaiha' of $R$. macrosepalum was investigated. In contrast to the gamopetalous corolla of the wild type, all sai-zaki cultivars formed the choripetalous corolla type, which consisted of 5 independent petals. The width of the leaf, sepal, and petal of all sai-zaki cultivars, except for the sepal of 'Ginno-zai', all tended to be narrower than the wild type; in particular, all lateral organs of 'Seigaiha' were extremely narrow compared with the wild type. In contrast to the normal pistil of the wild type, 'Hanaguruma' and 'Ginno-zai', normal and malformed pistils were observed in 'Seigaiha'. Epidermal cell size was not related to the narrowness of lateral organs in the wild-type and sai-zaki cultivars. These results indicate that the sai-zaki trait of materials, at least 'Seigaiha', would be a common mutation in the growth of lateral organs in the transverse plane. All sai-zaki cultivars showed fertility. The sai-zaki trait of old Japanese cultivars from the Edo era is expected to provide new breeding material that offers the opportunity to generate additional morphological novelties.

Key Words: azalea, choripetalous flower, gamopetalous flower, morphological analysis, sai-zaki form.

\section{Introduction}

The species of Rhododendron subgenus Tsutsusi section Tsutsusi (Ericaceae) are an important genetic resource for the breeding of evergreen azalea cultivars widely grown as ornamental shrubs or pot azaleas (Kobayashi et al., 2000). These species have been used in the breeding of hundreds of azalea cultivars produced since the Edo era (1603 to 1867) (Kunishige and Kobayashi, 1980, 2008).

The first monograph on azaleas, Kinshu-Makura, was written by Ito in 1692 and introduced 337 cultivars of azalea and Satsuki hybrids; the English translation was entitled A Brocade Pillow: Azaleas of Old Japan (Ito and Creech, 1984). Several cultivars mentioned in this monograph have been maintained by vegetative propagation to the present day and include plants that

Received; January 27, 2011. Accepted; August 5, 2011.

This study was supported by Grant-in-Aid for Scientific Research (KAKENHI No. 22580032) from Japan Society for the Promotion of Science (JSPS).

* Corresponding author (E-mail: nkobayashi@life.shimane-u.ac.jp). have particular mutations of the flower and leaf. Of the floral mutations, the use of double and hose-in-hose traits as breeding materials was recorded in the Azalea Research Notes 1917 and 1918 of the Kanagawa Agricultural Research Station, Japan (Kurashige and Kobayashi, 2008), however, other floral mutation traits have not been introduced into azalea breeding programs. Kobayashi et al. (2010) recently evaluated a cultivar possessing a long-lasting corolla among a collection of preserved old Japanese cultivars, with the purpose of assessing their application in breeding.

Our research is also focused on the interesting floral traits of narrow petals and/or staminoid petals. This mutational trait is called "sai-zaki"; "sai" means "split figure" and "zaki" means "flowering form". The sai-zaki trait is known in several Japanese evergreen azalea species and several cultivars mentioned in KinshuMakura.

The introduction of sai-zaki traits into azalea breeding is expected to result in singular flower forms. Sai-zaki cultivars has been registered in Satsuki ( $R$. indicum (L.) Sweet) and R. kaempferi cultivar groups, but they were not popular in other cultivar groups; however, new sai- 
zaki cultivars based on Japanese old cultivar have began to appear in Europe in recent years (Hortinno, http:// www.hortinno.com/p_787.htm). Thus, a detailed analysis of sai-zaki mutants will improve our knowledge concerning the morphological differences between the gamopetalous and choripetalous corolla forms. In this study, we examined the wild type of $R$. macrosepalum and 3 old sai-zaki cultivars possessing a narrow petal. The natural populations of $R$. macrosepalum are mainly distributed in central Honshu, Japan, but this species has not been used as breeding parents in recent new azalea cultivars. The sai-zaki cultivars in $R$. macrosepalum used in this study are known as old mutational cultivars, in particular, 'Hanaguruma' and 'Seigaiha' was introduced in Kinshu-makura. 'Seigaiha' had been recognized as R. lineariforium Sieb. \& Zucc. in 19th century (Wilson and Rehder, 1921; Yamazaki, 1996). The leaf and flower morphology of these cultivars was compared with the wild type, and pollen stainability and seed productivity were investigated to assess their applicability as breeding materials. These results reevaluate mutational old cultivars in R.macrosepalum, and provide basic information on the genetic mechanisms underlying the sai-zaki traits.

\section{Materials and Methods}

\section{Plant materials}

The wild species $R$. macrosepalum Maxim. and its cultivars 'Hanaguruma', 'Gin-no-zai', and 'Seigaiha' (Ito and Creech, 1984; Wilson and Rehder, 1921; Yamazaki, 1996; Yamazaki and Yamazaki, 1969, 1976) were used in this study (Fig. 1A-D). The flower of the wild type is purplish pink, those of 'Hanaguruma' and 'Seigaiha' are strong purplish pink, and that of 'Gin-nozai' is white (Mizuta et al., 2009). All plant material was obtained from the azalea resource collection of the Plant Breeding Laboratory of Shimane University.

\section{Measurement of floral organs and leaves}

In the flowering season from mid-April to mid-May 2009 , the maximum width and length of the petals and sepals, as well as length of the filaments and style, were measured. During the growing season, from late August to mid-October 2009, the maximum width and length of the larger 5 th-7th leaf from the shoot apex of currentyear branches were measured. The indexes of petal, sepal, and leaf were calculated by the length divided by the width.

\section{Observation of epidermal cells}

To investigate a possible relationship with organ width and length, the epidermal cell sizes on the adaxial and abaxial surfaces of the petal, sepal, and leaf of sai-zaki cultivars were compared to those of the wild type. Epidermal cells of the petal, sepal, and leaf were observed using SUMP (Suzuki's Universal Microprinting Method; SUMP Laboratory, Tokyo, Japan), which makes a celluloid replica of the organ surface, with a light microscope (Nikon XF-21, Nikon Co., Tokyo, Japan). Images were recorded with a digital camera (Nikon COOLPIX 8400, Nikon Co.). The epidermal cell width and length in the petal, sepal, and leaf were estimated from cell number per one field of vision in the microscope lens. Size data obtained from the diameter of the field of vision $(\phi 720 \mu \mathrm{m})$ were divided by the number of cells crosswise and lengthwise. The number of epidermal cells per size of organ was estimated and compared with the average size of each organ. The calculating formulas are as follows: Estimated number of cell per organ size $=$ average of organ size $(\mathrm{mm}) /$ $\phi 0.72 \mathrm{~mm}$ (diameter of the field of vision in the microscope lens) $\times$ number of cells in a field of view. Vertical bars show the standard deviation of the means of eight replications.
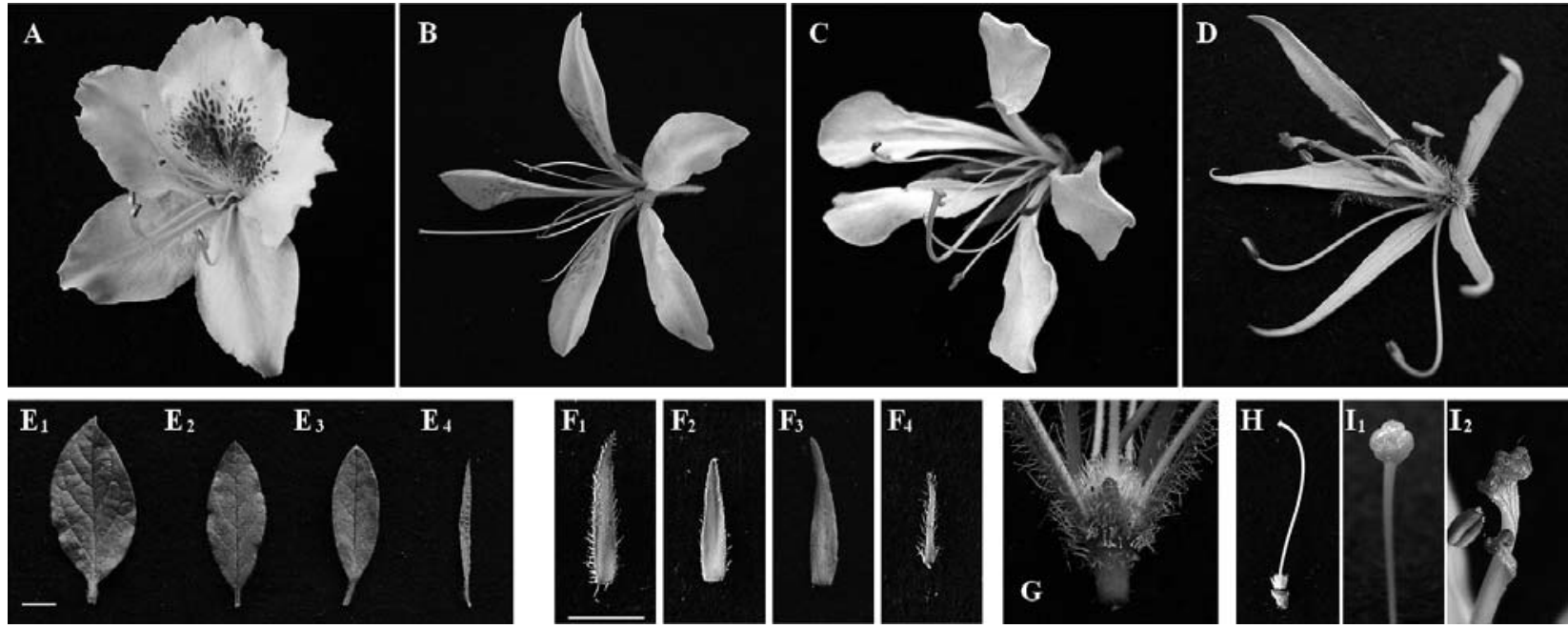

Fig. 1. Gross morphology of the flowers and leaves in R. macrosepalum (A, E1, F1, H), 'Hanaguruma' (B, E2, F2), 'Gin-no-zai' (C, E3, F3), 'Seigaiha' (D, E4, F4, G, I1, I2). Flower (A-D), leaf (E), sepal (F), small sepal of 'Seigaiha' (G), gynoecium of R. macrosepalum (H), normal (I1) and abnormal (I2) stigma of 'Seigaiha'. Bar $=10 \mathrm{~mm}$. 
Observation of leaf morphology and venation

The venation on the leaf abaxial surface and the leaf shape were observed using a stereomicroscope (WILD M8 Leica, Heerbrugg, Switzerland). Images were recorded with a digital camera.

Investigation of pollen stainability and seed productivity

Pollen grains were observed by light microscopy after staining with aceto-orcein. The ratio of stained pollen to total pollen was calculated. The seed productivity of sai-zaki cultivars was determined by crossing with the wild type, and the germinability of these obtained hybrid seeds was investigated. 'Gin-no-zai' was not used to cross as a seed parent.

\section{Results}

\section{Leaf morphology and venation}

The wild-type leaf shape was elliptic (Fig. 1E $\mathrm{E}_{1}$ ). The average leaf length and width were $60.6 \pm 3.4 \mathrm{~mm}$ and $31.2 \pm 3.3 \mathrm{~mm}$, respectively. The average leaf index was $1.9 \pm 0.2$ (Table 1 ). The shape of the leaf tip was slightly acute (Fig. 2A $\mathrm{A}_{1}$ ). Lateral veins branched from the midrib at about $5 \mathrm{~mm}$ intervals. In 'Hanaguruma' and 'Gin-nozai', the leaf shape was narrowly elliptic (Fig. $1 \mathrm{E}_{2}, \mathrm{E}_{3}$ ). The average leaf length of 'Hanaguruma' and 'Gin-nozai' was similar to that of the wild type $(58.9 \pm 3.8 \mathrm{~mm}$ and $53.3 \pm 4.6 \mathrm{~mm}$, respectively). The average leaf width of 'Hanaguruma' and 'Gin-no-zai' was narrower than the wild type $(20.9 \pm 2.1 \mathrm{~mm}$ and $17.6 \pm 2.2 \mathrm{~mm}$, respectively). The average leaf index of 'Hanaguruma' and 'Gin-no-zai' was $2.8 \pm 0.2$ and $3.1 \pm 0.2$, respectively. Their leaf shapes were narrower than the wild type (Table 1). The shape of the leaf tip in 'Hanaguruma' and
'Gin-no-zai' was acute (Fig. 2B ${ }_{1}, C_{1}$ ). Lateral veins diverging from the midrib were more widely spaced than in the wild type (Fig. 2B, C). The lamina margin in 'Ginno-zai' was curved towards the adaxial surface (data not shown). In 'Seigaiha', the leaf shape was linearlanceolate (Fig. 1E $\mathrm{E}_{4}$ ). The average leaf length and width of 'Seigaiha' were $54.9 \pm 3.8 \mathrm{~mm}$ and $3.8 \pm 0.8 \mathrm{~mm}$, respectively. The average leaf index of 'Seigaiha' was $15.2 \pm 3.1$ (Table 1), markedly narrower than that of the other plants. The leaf tip was acuminate (Fig. $\left.2 \mathrm{D}_{3}\right)$. The leaf margins were thickened. The leaves possessed only a main vein and veinlet; no lateral veins were observed (Fig. 2D).

Sepals

The sepals of the wild type and sai-zaki cultivars (Fig. 1F) were separated and not fused at all. The average sepal length and width in the wild type were $22.3 \pm$ $2.5 \mathrm{~mm}$ and $3.9 \pm 0.4 \mathrm{~mm}$, respectively. The average sepal index of the wild type was $5.8 \pm 0.8$ (Table 1 ). In 'Hanaguruma' and 'Gin-no-zai', the average sepal length was $18.2 \pm 1.5 \mathrm{~mm}$ and $22.9 \pm 3.2 \mathrm{~mm}$, respectively. The sepal length of 'Gin-no-zai' was similar to the wild type. The average sepal width of 'Hanaguruma' and 'Gin-nozai' was $3.1 \pm 0.4 \mathrm{~mm}$ and $4.4 \pm 0.4 \mathrm{~mm}$, respectively. The average sepal index of 'Hanaguruma' and 'Gin-nozai' was $6.0 \pm 1.1$ and $5.3 \pm 0.7$, respectively (Table 1 ). Thus, compared with the wild type, the sepal of 'Hanaguruma' was slightly narrower and that of 'Ginno-zai' was broader. In 'Seigaiha', the average sepal length was $15.5 \pm 2.2 \mathrm{~mm}$, shorter than the wild type, and the average sepal width was $1.4 \pm 0.2 \mathrm{~mm}$, which was less than half that of the wild type. The sepal index

Table 1. Size (mm) and index of lateral organs in R. macrosepalum, 'Hanaguruma', 'Gin-no-zai', 'Seigaiha'.

\begin{tabular}{|c|c|c|c|c|c|}
\hline & \multirow{2}{*}{ R. macrosepalum } & \multirow{2}{*}{ 'Hanaguruma' } & \multirow{2}{*}{ ‘Gin-no-zai’ } & \multicolumn{2}{|c|}{ 'Seigaiha' } \\
\hline & & & & normal organs & small sepal \\
\hline \multicolumn{6}{|l|}{ Leaf $(n=25)$} \\
\hline length & $60.6 \pm 3.4^{z} a^{y}$ & $58.9 \pm 3.8 \mathrm{a}$ & $53.3 \pm 4.6 \mathrm{~b}$ & $54.9 \pm 3.8 \mathrm{~b}$ & \\
\hline width & $31.2 \pm 3.3 \mathrm{a}$ & $20.9 \pm 2.1 \mathrm{~b}$ & $17.6 \pm 2.2 \mathrm{c}$ & $3.8 \pm 0.8 \mathrm{~d}$ & \\
\hline leaf index & $1.9 \pm 0.2$ & $2.8 \pm 0.2$ & $3.1 \pm 0.2$ & $15.2 \pm 3.1$ & \\
\hline \multicolumn{6}{|l|}{ Sepal $\left(n=40^{x}\right)$} \\
\hline length & $22.3 \pm 2.5 \mathrm{a}$ & $18.2 \pm 1.5 \mathrm{~b}$ & $22.9 \pm 3.2 \mathrm{a}$ & $15.5 \pm 2.2 \mathrm{c}$ & $3.3 \pm 1.2 \mathrm{~d}$ \\
\hline width & $3.9 \pm 0.4 \mathrm{a}$ & $3.1 \pm 0.4 \mathrm{~b}$ & $4.4 \pm 0.4 \mathrm{c}$ & $1.4 \pm 0.2 \mathrm{~d}$ & $1.6 \pm 0.3 \mathrm{~d}$ \\
\hline sepal index & $5.8 \pm 0.8$ & $6.0 \pm 1.1$ & $5.3 \pm 0.7$ & $11.8 \pm 3.0$ & $2.0 \pm 0.6$ \\
\hline \multicolumn{6}{|l|}{ Petal $(n=40)$} \\
\hline length & $39.1 \pm 2.5 \mathrm{a}$ & $43.8 \pm 2.3 \mathrm{~b}$ & $42.6 \pm 2.4 \mathrm{~b}$ & $34.2 \pm 2.0 \mathrm{c}$ & \\
\hline width & $19.9 \pm 1.8 \mathrm{a}$ & $13.0 \pm 1.4 \mathrm{~b}$ & $11.8 \pm 3.7 \mathrm{~b}$ & $5.5 \pm 0.8 \mathrm{c}$ & \\
\hline petal index & $2.0 \pm 0.2$ & $3.4 \pm 0.3$ & $4.0 \pm 1.5$ & $6.4 \pm 1.0$ & \\
\hline \multicolumn{6}{|l|}{ Stamen $(n=40)$} \\
\hline filament length & $35.0 \pm 4.1 \mathrm{a}$ & $36.8 \pm 3.7 \mathrm{a}$ & $34.9 \pm 4.9 \mathrm{a}$ & $31.8 \pm 3.2 \mathrm{~b}$ & \\
\hline \multicolumn{6}{|l|}{ Pistil (n=8) } \\
\hline style length & $39.1 \pm 0.9 \mathrm{a}$ & $48.8 \pm 2.4 \mathrm{~b}$ & $57.0 \pm 3.1 \mathrm{~b}$ & $37.9 \pm 3.2 \mathrm{a}$ & \\
\hline
\end{tabular}

z $\mathrm{Mean} \pm \mathrm{SD}$.

y Letters represent results from Tukey's multiple comparison test $(P<0.01)$ of each organ in wild-type and sai-zaki cultivars.

${ }^{x}$ Normal and small sepals of 'Seigaiha' are 32 and 8 replications, respectively. 
of 'Seigaiha' was $11.8 \pm 3.0$, that is, the sepal shape of 'Seigaiha' was markedly narrower than the wild type
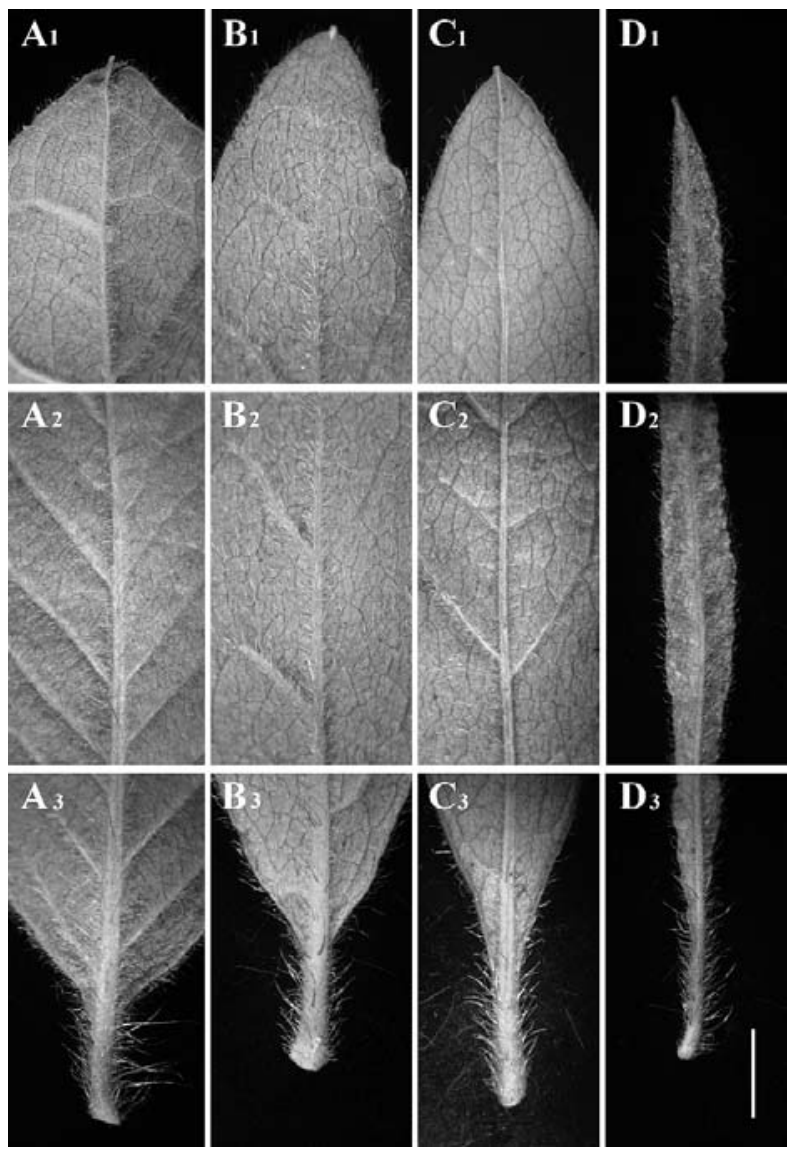

Fig. 2. Venation on the leaf adaxial surface of R. macrosepalum (A), 'Hanaguruma' (B), 'Gin-no-zai' (C), and 'Seigaiha' (D). A1D1 distal portion, A2-D2 medial portion, and A3-D3 proximal portion. $\mathrm{Bar}=5 \mathrm{~mm}$.
(Table 1). The sepal located opposite the main blotched petal was especially short (Fig. 1G). In this small sepal, the sepal index was $2.0 \pm 0.6$ (Table 1 ).

\section{Petals}

The corolla of the wild type was gamopetalous (Fig. 1A). In contrast, 'Hanaguruma', 'Gin-no-zai', and 'Seigaiha' possessed a choripetalous corolla comprising 5 separate petals (Fig. 1B-D). In 'Hanaguruma' and 'Gin-no-zai', the distal portion of the petal lamina was expanded (Fig. 1B, C). In 'Gin-no-zai', the expansion of the petal lamina was not uniform (Fig. 1C). The average petal index of 'Hanaguruma' and 'Gin-no-zai' was 3.4 \pm 0.3 and $4.0 \pm 1.5$, respectively showed that their petals were narrower than the wild type, which had a petal index of $2.0 \pm 0.2$. The average petal index of 'Seigaiha' was $6.4 \pm 1.0$; that is, the petals of 'Seigaiha' were markedly narrower than the wild type (Table 1 ). The petal lamina of 'Seigaiha' was narrow lanceolate, similar to the shape of the leaves (Fig. 1D).

\section{Stamens}

Flowers of the wild type contained 5 stamens. Flowers of 'Hanaguruma' contained 5-8 stamens, but frequently no anthers were developed. Flowers of 'Gin-no-zai' contained 5-10 stamens and 'Seigaiha' had 5-6 stamens (data not shown). The average filament length in the wild type was $35.0 \pm 4.1 \mathrm{~mm}$. The average filament length of 'Hanaguruma' and 'Gin-no-zai' was $36.8 \pm 3.7 \mathrm{~mm}$ and $34.9 \pm 4.9 \mathrm{~mm}$, similar to the wild type, respectively. In 'Seigaiha', the average filament length was $31.8 \pm$ $3.2 \mathrm{~mm}$ (Table 1).

Table 2. Estimated size of epidermal cells in lateral organs of R. macrosepalum,'Hanaguruma', 'Gin-no-zai', 'Seigaiha' $(\mu \mathrm{m})$.

\begin{tabular}{|c|c|c|c|c|c|}
\hline & \multirow{2}{*}{ R. macrosepalum } & \multirow{2}{*}{ 'Hanaguruma' } & \multirow{2}{*}{ 'Gin-no-zai' } & \multicolumn{2}{|c|}{ 'Seigaiha' } \\
\hline & & & & normal organs & small sepal \\
\hline \multicolumn{6}{|l|}{ Petal } \\
\hline adaxial cell length ${ }^{\mathrm{z}}$ & $38.0 \pm 2.2^{y}$ & $49.8 \pm 5.9$ & $45.7 \pm 7.7$ & $53.4 \pm 5.7$ & \\
\hline adaxial cell width & $37.0 \pm 3.4$ & $46.3 \pm 5.7$ & $38.3 \pm 5.2$ & $41.6 \pm 6.5$ & \\
\hline abaxial cell length & $37.9 \pm 5.6$ & $41.0 \pm 2.7$ & $36.3 \pm 3.7$ & $44.8 \pm 3.1$ & \\
\hline abaxial cell width & $31.3 \pm 3.5$ & $36.1 \pm 1.7$ & $30.2 \pm 1.4$ & $30.6 \pm 2.3$ & \\
\hline \multicolumn{6}{|l|}{ Sepal } \\
\hline adaxial cell length & $43.5 \pm 5.1$ & $44.1 \pm 6.3$ & $35.2 \pm 3.2$ & $55.1 \pm 6.8$ & $47.5 \pm 4.2$ \\
\hline adaxial cell width & $18.7 \pm 1.7$ & $24.6 \pm 1.5$ & $27.1 \pm 2.4$ & $23.3 \pm 1.9$ & $18.9 \pm 0.9$ \\
\hline abaxial cell length & $32.7 \pm 2.8$ & $35.0 \pm 3.5$ & $32.0 \pm 2.4$ & $41.4 \pm 3.2$ & $21.5 \pm 2.6$ \\
\hline abaxial cell width & $16.3 \pm 1.7$ & $21.7 \pm 1.4$ & $23.5 \pm 1.1$ & $16.3 \pm 1.4$ & $12.9 \pm 1.5$ \\
\hline \multicolumn{6}{|l|}{ Leaf } \\
\hline adaxial cell length & $24.1 \pm 1.2$ & $26.8 \pm 1.6$ & $25.2 \pm 2.4$ & $21.6 \pm 1.9$ & \\
\hline adaxial cell width & $21.9 \pm 1.3$ & $24.2 \pm 1.2$ & $24.0 \pm 3.0$ & $21.6 \pm 1.3$ & \\
\hline abaxial cell length & $21.5 \pm 1.1$ & $23.2 \pm 1.6$ & $23.4 \pm 2.3$ & $16.0 \pm 1.1$ & \\
\hline abaxial cell width & $19.8 \pm 2.1$ & $25.1 \pm 2.7$ & $21.6 \pm 1.2$ & $16.8 \pm 2.5$ & \\
\hline
\end{tabular}

${ }^{\mathrm{z}}$ Cell size $=720 \mu \mathrm{m} / \mathrm{number}$ of cells.

y $\operatorname{Mean} \pm \operatorname{SD}(\mathrm{n}=8)$ 


\section{Pistil}

The normal pistil of the wild type is shown in Figure $1 \mathrm{H}$. The pistil form of 'Hanaguruma' and 'Ginno-zai' was identical to that of the wild type. In the flower in 'Seigaiha', a split pistil was often observed (Fig. $1 \mathrm{I}_{2}$ ). The average style length of the wild type was $39.1 \pm 0.9 \mathrm{~mm}$. The average style length of 'Hanaguruma' and 'Gin-no-zai' was $48.8 \pm 2.4 \mathrm{~mm}$ and $57.0 \pm 3.1 \mathrm{~mm}$, respectively. In the normal style of 'Seigaiha', the average style length was $37.9 \pm 3.2 \mathrm{~mm}$, similar to the wild type (Table 1 ).

\section{Epidermal cells}

The width and length of the petal, sepal, and leaf of sai-zaki cultivars were not related to the epidermal cell size (Table 2). Epidermal cell shapes of the petal of all sai-zaki cultivars (Fig. $3 \mathrm{~B}_{1-2}, \mathrm{C}_{1-2}, \mathrm{D}_{1-2}$ ) were similar to the wild type (Fig. $3 \mathrm{~A}_{1-2}$ ). In the sepal and leaf, 'Hanaguruma' (Fig. 3B $\mathrm{B}_{3-6}$ ) and 'Gin-no-zai' (Fig. $3 \mathrm{C}_{3-6}$ ) have a similar epidermal cell shape to the wild type (Fig. $3 A_{3-6}$ ). In 'Seigaiha', the epidermal cell shape of the sepal and leaf were slightly narrower than the wild type (Fig. 3D $\mathrm{D}_{3-6}$ ). The number of epidermal cells of the petal, sepal, and leaf almost correlated with the organ size (Fig. 4).

\section{Pollen stainability and seed productivity}

Pollen grains of the sai-zaki cultivars have 100\% stainability by aceto-orcein (data not shown) and developed normally, identical to those of the wild type. In reciprocal crosses between sai-zaki cultivars and the wild type of $R$. macrosepalum, all cross combinations except 'Gin-no-zai' $\times$ R. macrosepalum developed fruit and obtained seeds. The germination rate of hybrid seeds was $11.5 \%$ to $88.6 \%$ (Table 3 ). The extremely low germination rate was confirmed in the cross combination of 'Hanaguruma' $\times$ R. macrosepalum.

\section{Discussion}

In the historical development of Japanese azalea cultivars, natural hybrids and mutants were first selected from wild populations and cultivated in a daimyo's garden (a feudal lord's garden). Diversification of azalea cultivars was achieved based on these collected plants and selection of seedlings in the mid-Edo period, from the mid-17th century to the beginning of the 18th century (Kobayashi et al., 2007; Kunishige and Kobayashi, 1980).

Historical notes indicate that the first breeding program was started in the last part of the Meiji period in Japan (Miyazawa, 1940). Detailed investigation of inheritance and the breeding of novel flower colors and shapes were undertaken in this program (Kurashige and Kobayashi, 2008). In modern times, Belgian pot azalea cultivars have been developed based on Japanese and Chinese azaleas (Riek et al., 1999) and have been used for systematic investigation of the inheritance of flower colors and shapes (Heursel, 1975, 1976; Heursel and

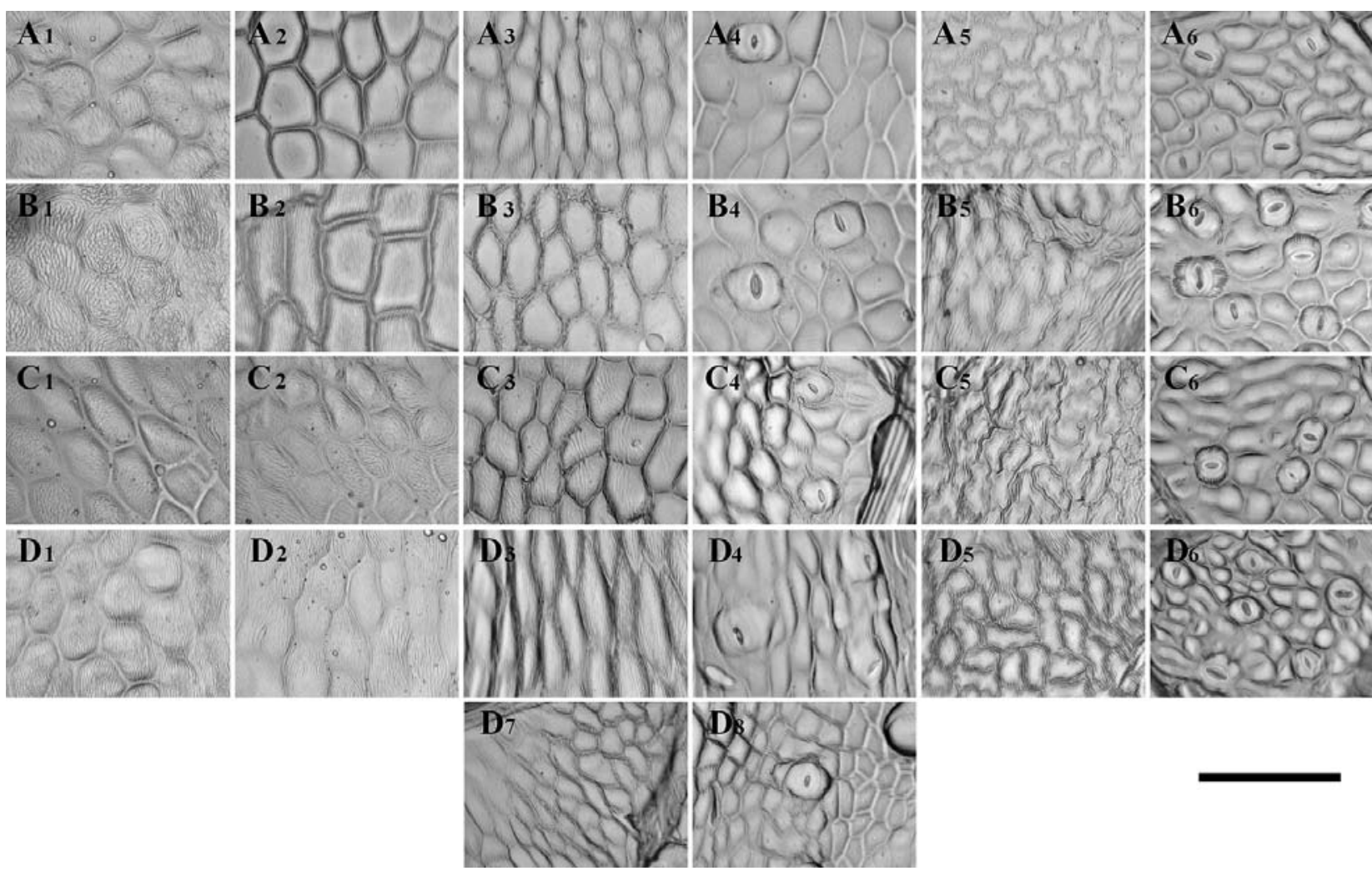

Fig. 3. Epidermal cells of the petal $(1,2)$, sepal $(3,4,7,8)$, and leaf $(5,6)$ of $R$. macrosepalum (A), 'Hanaguruma' (B), 'Gin-no-zai' (C), 'Seigaiha' (D). Adaxial surface $(1,3,5,7)$ and abaxial surface $(2,4,6,8)$. Bar $=100 \mu \mathrm{m}$. 

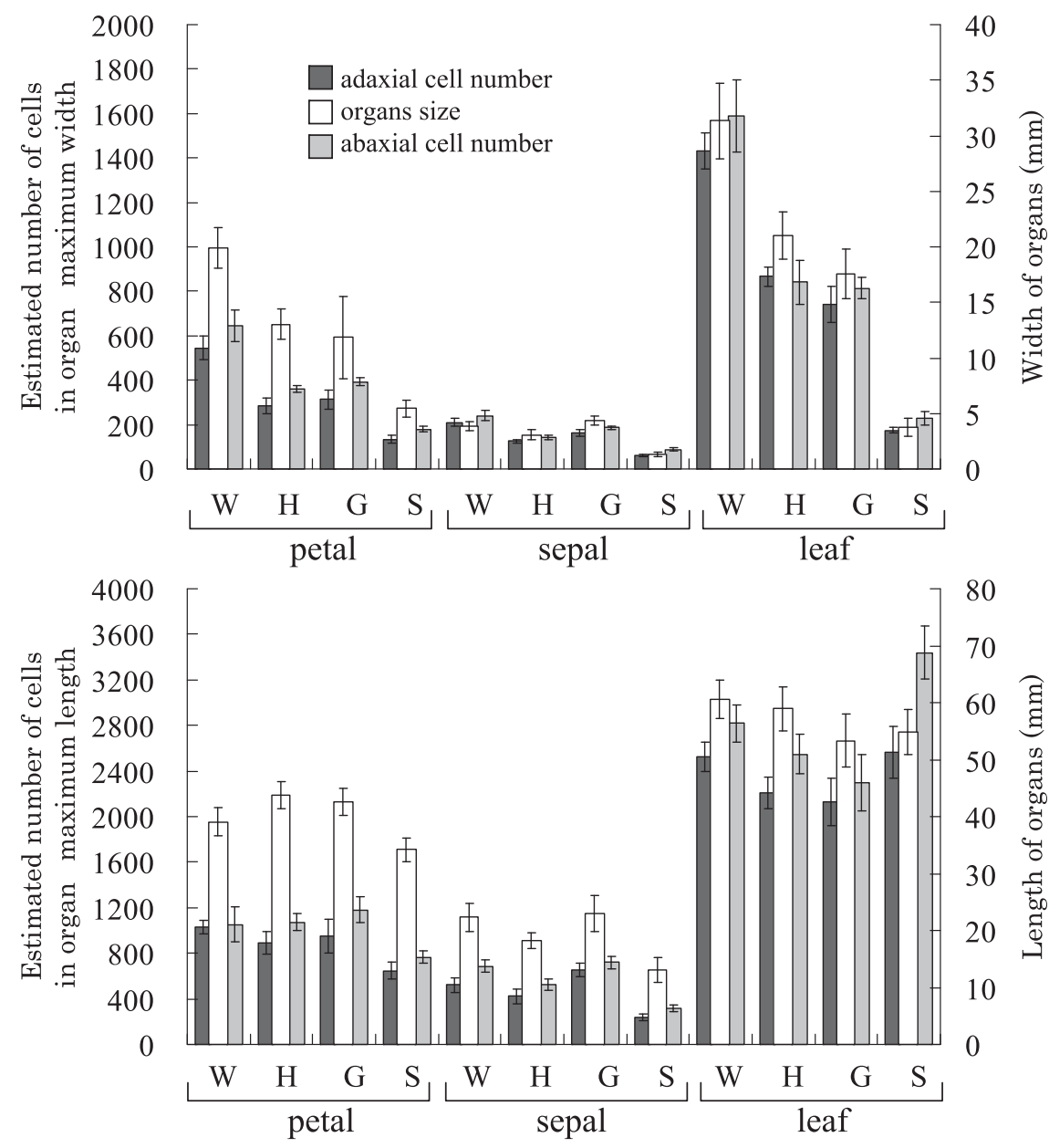

Fig. 4. Comparison between the number of epidermal cells and the size of petal, sepal, and leaf. Wild-type (W), 'Hanaguruma' (H), 'Gin-nozai' (G), 'Seigaiha' (S). The estimated number of cell per organ size = average of organ size $(\mathrm{mm}) / \phi 0.72 \mathrm{~mm}$ (diameter of the field of vision in the microscope lens) $\times$ number of cells in a field of view. Vertical bars show the SD of the means of eight replications.

Table 3. Obtained number of seeds and germination rate in reciprocal croosses between R. macrosepalum and sai-zaki cultivars.

\begin{tabular}{|c|c|c|c|}
\hline seed parent & pollen parent & average number of seeds in a fruit & $\%$ of seeds germinating \\
\hline R. macrosepalum & × 'Hanaguruma' & $315.0(2 / 2)^{\mathrm{z}}$ & $88.5(46 / 52)^{y}$ \\
\hline R. macrosepalum & $\times$ 'Gin-no-zai' ${ }^{x}$ & $399.0(2 / 3)$ & $59.6(31 / 52)$ \\
\hline R. macrosepalum & $\times$ 'Seigaiha' & $443.5(4 / 4)$ & $51.9(27 / 52)$ \\
\hline 'Hanaguruma' & $\times \quad$ R. macrosepalum & $320.0(5 / 5)$ & $11.5(6 / 52)$ \\
\hline 'Seigaiha' & $\times \quad$ R. macrosepalum & $993.0(2 / 2)$ & $88.6(46 / 52)$ \\
\hline
\end{tabular}

$\mathrm{z}$ (number of obtained seed/number of crossed flowers)

${ }^{y}$ (number of germinated seed/number of seeds sown)

${ }^{x}$ The reverse cross combination, 'Gin-no-zai' $\times$ R. macrosepalum was not tested.

Garretsen, 1989; Heursel and Horn, 1977). In azalea breeding programs except for Satsuki groups, extreme floral mutations such as those possessed by narrow saizaki cultivars have not been utilized as breeding materials in recent years.

Morning glory (Ipomoea nil), which is a classic garden plant, as is azalea, has given rise to a variety of morphological mutants. These mutations have been investigated systematically to determine their inheritance (Yoneda, 1977). One of these mutants, maple-willow $\left(m^{w}\right)$, has the characteristics of considerably narrowed leaves, sepals, and petals, and split stigma and styles owing to an inactive marginal meristem. Recently, it was reported that the leaf and floral organ morphological characteristics of the $m^{w}$ mutant are the result of a pleiotropic mutation (Kajita and Nishino, 2009a, b). It is hypothesized that the sai-zaki cultivars used in this study possess a similar mutation to $m^{w}$. In this study, we compared the epidermal cell size and width of the leaves, sepals, and petals in wild-type and sai-zaki cultivars. In the size of the epidermal cells of these organs, no important trend for the determination of organ size was 
seen between wild-type and sai-zaki cultivars. In Figure 4, as for the number of epidermal cells corresponding to organ size, the same tendency was confirmed in all plants. This result means that the size of organs in sai-zaki cultivars is decided by the number of cells. The indexes of the leaf, sepal, and petal of 'Seigaiha' showed that these organs are markedly narrower than the wild type. The occurrences of these characteristics in homologous organs support the suggestion that 'Seigaiha' possesses a pleiotropic mutation in the development of lateral organs in the transverse plane. On the other hand, in 'Hanaguruma' and 'Gin-no-zai', the sepal index of 'Hanaguruma' did not show a definite difference from the wild type, and that of 'Gin-no-zai' was broader than the wild type. Furthermore, the pistils of two cultivars took the normal form; therefore, it is difficult to conclude that these traits depend on a pleiotropic mutation. R. ripense Makino, which belongs to the same series as $R$. macrosepalum, has 10 stamens and narrower leaves than R. macrosepalum. The characteristics of leaf shape and stamen number in 'Hanaguruma' and 'Gin-no-zai' suggest the genetic effect of $R$. ripense (Inobe, 1971; Kobayashi et al., 2008).

In Rhododendron, morphological observations have been undertaken for the purpose of taxonomic classification and cultivar identification (Chamberlain and Rae, 1990; Yamazaki, 1996); however, mutational morphological characteristics of azalea cultivars have not been analyzed in detail. The investigation of azalea mutants, such as sai-zaki and misome-sho (Kobayashi et al., 2010), and the building of a database on these mutations will be extremely useful for traditional and molecular breeding.

Viable seedlings were obtained in all tested cross combinations. The low seed germination rate of the cross combination 'Hanaguruma' $\times R$. macrosepalum have been caused by drought under germination bed conditions. A split pistil was often observed in 'Seigaiha', but crosses using a normally developed pistil of 'Seigaiha' and wild-type pollen were successful, and these hybrid seedlings developed normal leaves. In addition, the progeny of a cross between 2 sai-zaki cultivars have narrow leaves (unpublished data). The inheritance of homological characteristics of flowers will be clarified in the near future. The 3 sai-zaki cultivars in R. macrosepalum cultivar groups will be available to use as breeding resources to generate additional morphological novelties.

We are investigating the genetic basis of flower form through analysis of MADS-box genes in azalea; however, the mutation of sai-zaki cultivars of R. macrosepalum used in this study, at least 'Seigaiha', which shows pleiotropic leaf and floral organ phenotyes, probably cannot be explained only in terms of MADSbox genes, which are specific to phenotype expression in floral organs. Recently, research has focused on the apical meristem during the development of lateral organs such as leaves and floral organs. The maw and chsu double mutation in petunia, which results in an organ shape similar to that of 'Seigaiha', has been reported (Vandenbussche et al., 2009). We are analyzing these homeotic genes in order to characterize the sai-zaki mutation.

\section{Literature Cited}

Chamberlain, D. F. and S. J. Rae. 1990. A revision of Rhododendron. IV Subgenus Tsutsusi. Edinb. J. Bot. 47: 89200.

Heursel, J. 1975. Inheritance of the flavonols azaleatin and quercetin in Rhododendron simsii Planch. and Rh. obtusum Planch. Z. Pflanzenzuchtg. 74: 62-70.

Heursel, J. 1976. Die vererbung des merkmals "hose in hose" (Doppelkronigkeit) bei Azaleen. Gartenwelt. 76: 111-113 (In German).

Heursel, J. and F. Garretsen. 1989. Inheritance of corolla size, number of stamens and percentage of plants with petaloid stamens in evergreen azaleas (Rhododendron Subsect. obtusa). Plant Breed. 103: 304-309.

Heursel, J. and W. Horn. 1977. A hypothesis on the inheritance of flower colours and flavonoids in Rhododendron simsii Planch. Z. Pflanzenzuchtg. 79: 238-249.

Ito, I. and J. L. Creech. 1984. A Brocade Pillow: Azaleas of Old Japan. John Weatherhill, Inc., New York and Tokyo.

Inobe, T. 1971. Murasaki ryukyu tsutsuji no jisei ni kansuru iti kosatu. J. Jpn. Bot. 46: 311-315 (In Japanese).

Kajita, Y. and E. Nishino. 2009a. Morphology and anatomy of leaves and flowers of wild-type and pleiotropic maple-willow mutants in Japanese morning glory (Ipomea nil). J. Japan. Soc. Hort. Sci. 78: 369-380.

Kajita, Y. and E. Nishino. 2009b. Development of leaves and flowers in the wild type and pleiotropic maple-willow mutant of Japanese morning glory (Ipomea nil). J. Japan. Soc. Hort. Sci. 78: 469-477.

Kobayashi, N., T. Handa, I. Miyajima, K. Arisumi and K. Takayanagi. 2007. Introgressive hybridization between Rhododendron kiusianum and R. kaemferi (Ericaceae) in Kyushu, Japan based on chloroplast DNA markers. Edinb. J. Bot. 64: 283-293.

Kobayashi, N., T. Handa, K. Yoshimura, Y. Tsumura, K. Arisumi and K. Takayanagi. 2000. Evidence for introgressive hybridization based on chloroplast DNA polymorphisms and morphological variation in wild evergreen azalea populations of the Kirishima mountains, Japan. Edinb. J. Bot. 57: 209219.

Kobayashi, N., M. Ishihara, M. Ohtani, A. Nakatsuka, K. S. Cheon, D. Mizuta and K. Tasaki. 2010. Evaluation and application of the long-lasting flower trait (Misome-Sho) of azalea cultivars. Acta Hort. 855: 165-168.

Kobayashi, N., M. Oji, K. Ureshino, A. Nakatsuka and T. Hosoki. 2008. Evaluation of genetic resources of Rhododendron ripense Makino in San-in area, Japan, based on morphological characters and chloroplast DNA polymorphism. Hort. Res. (Japan) 7: 181-187 (In Japanese with English abstract).

Kunishige, M. and Y. Kobayashi. 1980. Chromatographic identification of Japanese azalea species and their hybrids. p. 277-287. In: J. L. Luteyn and M. E. O’brien (eds.). Contribution toward a classification of Rhododendron. New York Bot. Garden, New York.

Kurashige, Y. and N. Kobayashi. 2008. Evergreen azalea cultivars 
and breeding trends in the Taisho era inferred by discovered "azalea research notes" of Kanagawa agricultural research station. Hort. Res. (Japan) 7: 323-328 (In Japanese with English abstract).

Miyazawa, B. 1940. Kaboku engei (In Japanese). Yasaka Shobo, Tokyo.

Mizuta, D., T. Ban, I. Miyajima, A. Nakatsuka and N. Kobayashi. 2009. Comparison of flower color with anthocyanin composition patterns in evergreen azalea. Sci. Hortic. 122, 594-602.

Riek, J. D., J. Dendauw, M. Mertens, M. D. Loose, J. Heursel and E. V. Blockstaele. 1999. Validation of criteria for the selection of AFLP markers to assess the genetic variation of a breeders' collection of evergreen azaleas. Theor. Appl. Genet. 99: 11551165 .

Vandenbussche, M., A. Horstman, J. Zethof, R. Koes, A. S. Rijpkema and T. Gerats. 2009. Differential recruitment of
WOX transcription factors for lateral development and organ fusion in petunia and Arabidopsis. Plant Cell 21: 2269-2283.

Wilson, E. H. and A. Rehder. 1921. A monograph of azaleas. Theophrastus. Little Compton, Rhode Island.

Yamazaki, T. 1996. A revision of the genus Rhododendron in Japan, Taiwan, Korea, and Sakhalin. Tsumura Laboratory, Tokyo.

Yamazaki, T. and F. Yamazaki. 1969. The cultivars of Rhododendron macrosepalum. J. Jpn. Bot. 44: 282-285 (In Japanese).

Yamazaki, T. and F. Yamazaki. 1976. Motitsutsuji, oryukyu, shiroryukyu kei no hinshu. p. 148-150. In: Garden life (ed.). Garden series: Tsutsuji, sono shurui to saibai (In Japanese). Seibundoshinkosha, Tokyo.

Yoneda, Y. 1977. Totsuzen henitai no keitai. p. 98-121. In: H. Kihara and H. Yamaguchi (eds.). Keitai keisei to totuzen heni (In Japanese). Shokabo, Tokyo. 